\title{
Influence of cultivation intensity on plant health and yield variability of winter wheat varieties
}

\section{Wpływ intensywności uprawy na zdrowotność roślin oraz zmienność plonowania odmian pszenicy ozimej}

\author{
Renata Kieloch ${ }^{1 *}$, Tomasz Kulon ${ }^{2}$
}

\begin{abstract}
Summary
The field studies were performed within Post-Registration Variety Testing Agrotechnical System (PDO) to evaluate yield variability and health status of eighteen winter wheat cultivars depending on cultivation intensity during 2016-2018. The trials compared standard variant with intensive variant of cultivation, which included higher level of nitrogen fertilization, application of fungicides and growth retardants, and foliar nutrition using multicomponent product. The observations performed in 2016 and 2017 revealed that plants were infected by septoria tritici bloth (Septoria tritici). The highest differences between the variants were found for KWS Dakotana and Belissa in both years of disease occurrence. Belissa cultivar was characterized by the lowest yield at both variants of cultivation. At standard variant, the highest yielding varieties were Artist, Linus, KWS Kiran, whereas at intensive variant KWS Ozon and Ostroga. No yield variability of the tested varieties for standard variant was proved, while the most variable yields were recorded for KWS Ozon, Patrias, Delawar at intensive variant.
\end{abstract}

Key words: winter wheat varieties, agrotechnical level, septoria tritici bloth, grain yield, plant infection

\section{Streszczenie}

W latach 2016-2018 wykonano badania polowe w ramach Porejestracyjnego Doświadczalnictwa Polowego (PDO) nad oceną zmienności plonowania i zdrowotności łanu 18 odmian pszenicy ozimej w zależności od intensywności uprawy. Porównywano wariant standardowy z wariantem intensywnym uprawy (zwiększone nawożenie azotowe + stosowanie fungicydów i antywylegaczy + dokarmianie dolistne preparatem wieloskładnikowym). W latach 2016-2017 odnotowano porażenie septoriozą paskowaną liści (Septoria tritici). Największe różnice w porażeniu roślin pomiędzy badanymi wariantami stwierdzono dla odmian KWS Dakotana i Belissa w obu latach występowania choroby. Odmiana Belissa odznaczała się najniższym poziomem plonowania w obu wariantach uprawy. W wariancie standardowym najlepiej plonowały odmiany pszenicy ozimej Artist, Linus i KWS Kiran, natomiast w wariancie intensywnym KWS Ozon i Ostroga. Nie wykazano zmienności w plonowaniu odmian pszenicy uprawianych w wariancie standardowym, zaś w wariancie intensywnym zmienne plony dawały odmiany pszenicy ozimej KWS Ozon, Patrias i Delawar.

Słowa kluczowe: odmiany pszenicy ozimej, poziom agrotechniki, septorioza paskowana liści pszenicy, plon ziarna, porażenie roślin

\footnotetext{
${ }^{1}$ Instytut Uprawy Nawożenia i Gleboznawstwa - Państwowy Instytut Badawczy

Zakład Herbologii i Technik Uprawy Roli

Orzechowa 61, 50-540 Wrocław

${ }^{2}$ Stacja Oceny Odmian w Zybiszowie

Zybiszów 1, 55-080 Kąty Wrocławskie

*corresponding author: r.kieloch@iung.wroclaw.pl
} 


\section{Wstęp / Introduction}

Pszenica ozima (Triticum aestivum L.) jest gatunkiem wiodącym pod względem zajmowanego areału w Polsce, stąd też istnieje ciągła potrzeba prac nad wprowadzaniem do uprawy nowych, ulepszonych odmian o pożądanych przez producentów rolnych cechach. Znaczenie pszenicy ozimej w strukturze agrarnej naszego kraju ma swoje odzwierciedlenie w ilości zarejestrowanych odmian obecnie w krajowym rejestrze odmian jest ich 121 (Lista odmian roślin rolniczych 2018).

Podstawową cechą uprawianej odmiany decydującą o opłacalności jej uprawy jest wysokość plonowania. Potencjał plonotwórczy może być jednak w pełni wykorzystany, gdy zapewnimy roślinom możliwie najbardziej dogodne warunki wzrostu. Są one kształtowane przez stosowaną agrotechnikę, przebieg pogody oraz środowisko glebowe. Intensyfikacja technologii uprawy w postaci zwiększonego nawożenia oraz zastosowania pełnej ochrony roślin przyczynia się do wzrostu poziomu ich plonowania (Jarecki i wsp. 2014; Kołodziejczyk i Szmigiel 2014). Odmiany danego gatunku różnią się pod względem reakcji na warunki siedliskowe oraz stosowaną agrotechnikę, w związku z czym mogą dawać mniej lub bardziej zróżnicowane $\mathrm{w}$ latach plony. Preferowane są odmiany plonujące stabilnie w zmiennych warunkach środowiska i stosowanej technologii uprawy (Weber i Bujak 2016). Ocena stabilności plonowania odmian w zmiennych warunkach klimatyczno-glebowych oraz przy zróżnicowanym poziomie agrotechniki może być pomocna dla rekomendacji odmian do uprawy w danym regionie z uwzględnieniem stosowanej technologii produkcji.

Jednym z czynników wpływających na wysokość uzyskanego plonu jest zdrowotność roślin. Porażenie upraw przez grzyby patogeniczne powoduje straty w plonach, których poziom może być zróżnicowany w zależności od odmiany, warunków meteorologicznych oraz technologii uprawy (Gala-Czekaj i wsp. 2013; Piekarczyk i Lemańczyk 2013). Można je minimalizować stosując ochronę fungicydową, co jednak nie jest obojętne dla środowiska naturalnego. Stąd też jedną ze strategii w integrowanej produkcji pszenicy ozimej jest wykorzystanie odmian o zwiększonej odporności na choroby.

Celem badań było określenie wpływu intensywności uprawy na zdrowotność łanu oraz wysokość i zmienność plonowania odmian pszenicy ozimej uprawianej na glebie lekkiej w warunkach klimatycznych Dolnego Śląska.

\section{Materiały i metody / Materials and methods}

W latach 2016-2018 wykonano doświadczenia w ramach Porejestracyjnego Doświadczalnictwa Odmianowego (PDO) i zlokalizowano je na polu uprawnym w Jelczu-
-Laskowicach (Instytut Uprawy Nawożenia i Gleboznawstwa - Państwowy Instytut Badawczy) na glebie kompleksu żytniego dobrego. Założono je metodą pasów prostopadłych w dwóch powtórzeniach. Pszenicę wysiano w pierwszej dekadzie października, w ilości pozwalającej uzyskać obsadę 450 szt. $/ \mathrm{m}^{2}$. Powierzchnia każdego poletka doświadczalnego wynosiła $12 \mathrm{~m}^{2}$.

Badaniami objęto 18 odmian pszenicy ozimej, tj. KWS Ozon, Patrias, Artist, RGT Kilimanjaro, Ostroga, Linus, KWS Livius, KWS Dakotana, KWS Loft, Belissa, Consus, Delawar, Janosch, Bonanza, Hybery, Kometa, KWS Kiran, LG Jutta. Pszenicę uprawiano w dwóch wariantach: standardowym - A1 i intensywnym - A2. Intensywna technologia uprawy różniła się od standardowej zwiększonym o $40 \mathrm{~kg} /$ ha nawożeniem azotowym, zastosowaniem ochrony fungicydowej, zastosowaniem antywylegacza oraz dolistnym dokarmianiem roślin preparatem wieloskładnikowym. Pozostałe zabiegi ochrony roślin oraz nawożenie fosforem i potasem były takie same dla obu wariantów uprawy.

W fazie kłoszenia pszenicy określono stopień porażenia roślin przez patogeny grzybowe posługując się skalą 9-stopniową, gdzie 9 - oznacza brak porażenia, 1 - poletko całkowicie porażone. W fazie dojrzałości pełnej zebrano ziarno, a plon określono przeliczając na 14\% wilgotności ziarna.

Obliczenia statystyczne wykonano za pomocą programu Sergen 4 oddzielnie dla wariantu standardowego (A1) i intensywnego (A2) biorąc za podstawę plon uzyskany $\mathrm{z}$ każdego poletka $\mathrm{w}$ ciągu trzech lat. W celu oceny zmienności plonowania odmian pszenicy ozimej w latach wykorzystano analizę statystyczną zaproponowaną przez Calińskiego i wsp. (1987a, b), która opiera się na poniższym modelu matematycznym:

$$
\mathrm{Y}_{\mathrm{ik} *}=\mu_{\mathrm{i}}+\alpha_{\mathrm{i}}^{\mathrm{E}}(\mathrm{k})+\mathrm{e}_{\mathrm{ik}}
$$

$\mu_{\mathrm{i}}$ - przeciętny potencjalny plon odmiany ,i”, $\alpha^{\mathrm{E}}{ }_{\mathrm{i}}(\mathrm{k})$ plonowanie odmiany , i” w roku „,k”, $\mathrm{e}_{\mathrm{ik}}$ - średni błąd ważony dla odmiany ,i” w roku ,k”.

Obliczenia wykonano oddzielnie dla wariantu standardowego i intensywnego.

\section{Wyniki i dyskusja / Results and discussion}

W tabeli 1. przedstawiono średnie miesięczne wartości temperatury i sumy opadów w analizowanym okresie. Przebieg pogody w miesiącach zimowych w analizowanych latach badań był korzystny dla przezimowania pszenicy ozimej. Okres wiosenny w latach 2016 i 2017 odznaczał się optymalną dla tej pory roku sumą opadów oraz średnimi miesięcznymi temperaturami, co sprzyjało wzrostowi i rozwojowi pszenicy ozimej. W lipcu 2017 roku zanotowano najwyższy w całym okresie badawczym poziom opadów 
deszczu, jednak nie wpłynęło to ujemnie na stan roślin oraz nie opóźniło zbioru ziarna. W okresie wiosenno-letnim 2018 roku wystąpiły znaczne deficyty opadów, co odbiło się negatywnie na wzroście i kondycji roślin.

Zdrowotność łanu pszenicy ozimej zależała od przebiegu pogody w sezonach wegetacyjnych. W latach umiarkowanie wilgotnych (2016-2017) odnotowano wystąpienie na roślinach objawów septoriozy paskowanej liści (Septoria tritici). Ostatni rok badań (2018) odznaczał się znacznym niedoborem opadów, w związku z czym nie zaobserwowano chorób na pszenicy ozimej (tab. 2). Nieco większe porażenie roślin przez tego patogena wystąpiło w pierwszym roku badań (2016). W tym sezonie, w największym stopniu zainfekowane były odmiany pszenicy ozimej KWS Dakotana, Belissa i Delawar uprawiane w wariancie standardowym. Były to jednocześnie przypadki największego porażenia roślin w analizowanym trzyleciu. W obu latach wystąpienia choroby (2016 i 2017), podniesienie poziomu agrotechniki $\mathrm{w}$ niewielkim stopniu poprawiło zdrowotność badanych odmian pszenicy ozimej, z wyjątkiem najbardziej porażonych odmian KWS Dakotana i Belissa.

Uzyskane plony zostały poddane szczegółowej analizie statystycznej, aby ocenić zmienność plonowania odmian w latach dla każdego $\mathrm{z}$ wariantów uprawy oddzielnie. W celu weryfikacji hipotez ogólnych o równości efektów głównych dla: odmian, lat oraz braku interakcji odmian z latami została przeprowadzona analiza wariancji (tab. 3). W przeprowadzonej analizie powyższe hipotezy zostały odrzucone na poziomie istotności $\alpha=0,05$ dla wariantu intensywnego, natomiast dla wariantu standardowego przyjęto hipotezę o braku interakcji odmian z latami.

Tabela 4. przedstawia wyniki analizy szczegółowej badanych odmian ze względu na ich plon i interakcję z latami badań. Efekty główne odmian przedstawiają odchylenia wielkości plonowania poszczególnych odmian dla średniej ogólnej z odmian i lat. W wariancie standardowym odmiany pszenicy ozimej Artist, Linus i KWS Kiran plonowały istotnie wyżej w porównaniu do średniej ogólnej. Pomimo, że nie stwierdzono istotnej interakcji odmian z latami, jednak niska wartość statystyki F dla interakcji wskazuje na to, że odmiany te jednocześnie odznaczają się najniższą zmiennością plonowania spośród wszystkich badanych odmian. Najsłabiej w wariancie standardowym plonowały odmiany Belissa i Patrias dając istotnie niskie plony w stosunku do średnich plonów z doświadczenia. W przypadku odmiany Belissa, podobną zależność stwierdzono również dla zwiększonego poziomu agrotechniki. Natomiast wyższym poziomem plonowania w powyższych warunkach odznaczały się odmiany pszenicy ozimej KWS Ozon i Ostroga. Istotnie wyższe wartości statystyki F dla interakcji genotypów z latami wyliczone dla odmian KWS Ozon, Patrias i Delawar wskazują na dużą zmienność ich plonowania w latach badań. Natomiast najniższe wartości statystyki F uzyskano dla odmian KWS Livius, Hybery i Kometa, które świadczą o tym, że dają one stabilne plony w warunkach stosowania intensywnej technologii uprawy.

Rysunek 1. przedstawia analizę składowych głównych dla interakcji odmian z latami dla wariantu standardowego (A1) oraz intensywnego (A2). W obu wariantach największym udziałem w wielkości interakcji odznaczały się odmiany KWS Ozon, Artist i Delawar, co jest określone przez największą odległość punktów reprezentujących te odmiany od środka układu współrzędnych. Świadczy to o tym, że odmiany te dawały najbardziej zmienne plony w badanym okresie. $\mathrm{W}$ wariancie standardowym punkty reprezentujące odmiany Artist i KWS Kiran położone są najbliżej centrum układu, co świadczy o tym, że spośród badanych odmian dają najbardziej stabilne plony. W wariancie intensywnym najbardziej stabilnymi plonami odznaczają się odmiany pszenicy ozimej KWS Livius i Kometa.

Wykorzystanie potencjału uzyskanego w procesie hodowlanym danej odmiany do obrony przed patogenami jest jedną $\mathrm{z}$ metod stosowanych $\mathrm{w}$ integrowanej ochronie upraw pszenicy ozimej przed chorobami. Potencjał ten w znacznym stopniu modyfikowany jest przez warunki

Tabela 1. Dane meteorologiczne dla badanego okresu

Table 1. Meteorogical data for the experimental period

\begin{tabular}{|c|c|c|c|c|c|c|c|c|c|c|c|c|c|}
\hline \multirow{2}{*}{$\begin{array}{l}\text { Rok } \\
\text { Year }\end{array}$} & \multirow{2}{*}{$\begin{array}{c}\text { Czynnik } \\
\text { pogodowy } \\
\text { Weather factor }\end{array}$} & \multicolumn{12}{|c|}{ Miesiące - Months } \\
\hline & & IX & X & XI & XII & I & II & III & IV & V & VI & VII & VIII \\
\hline $2015 /$ & $\mathrm{T}\left[{ }^{\circ} \mathrm{C}\right]$ & 14,8 & 8,1 & 6,3 & 5,7 & 3,0 & 3,9 & 4,3 & 8,8 & 15,0 & 18,6 & 19,3 & 18,1 \\
\hline 2016 & $\mathrm{O}[\mathrm{mm}]$ & 16,6 & 19,2 & 39,8 & 17,0 & 19,1 & 53,3 & 38,3 & 35,9 & 20,7 & 55,6 & 89,8 & 23,8 \\
\hline $2016 /$ & $\mathrm{T}\left[{ }^{\circ} \mathrm{C}\right]$ & 16,3 & 8,3 & 2,7 & 1,5 & $-3,4$ & 1,2 & 6,8 & 8,0 & 14,0 & 18,5 & 19,0 & 19,8 \\
\hline 2017 & $\mathrm{O}[\mathrm{mm}]$ & 23,8 & 67,0 & 67,0 & 25,0 & 11,8 & 18,8 & 28,3 & 52,3 & 22,5 & 63,4 & 106,1 & 49,2 \\
\hline 2017/ & $\mathrm{T}\left[{ }^{\circ} \mathrm{C}\right]$ & 13,3 & 10,9 & 5,5 & 2,4 & 3,3 & $-2,7$ & 1,4 & 18,3 & 16,8 & 18,7 & 19,8 & 21,2 \\
\hline 2018 & $\mathrm{O}[\mathrm{mm}]$ & 84,7 & 61,3 & 26,9 & 14,0 & 15,6 & 0,5 & 9,6 & 11,4 & 20,6 & 25,6 & 54,9 & 11,5 \\
\hline
\end{tabular}

$\mathrm{T}$ - temperatura - temperature, $\mathrm{O}$ - opad - rainfall 
Tabela 2. Porażenie (w skali $9^{\circ}$ ) odmian pszenicy ozimej w różnych wariantach uprawy

Table 2. Infestation (in $9^{\circ}$ scale) of winter wheat cultivars under different variant of cultivation

\begin{tabular}{|c|c|c|c|c|c|c|c|c|c|c|c|c|c|c|c|c|c|c|}
\hline $\begin{array}{c}\text { Wariant uprawy } \\
\text { Variant } \\
\text { of cultivation }\end{array}$ & $\begin{array}{l}\text { J̃ } \\
0 \\
0 \\
n \\
3\end{array}$ & 胥 & $\stackrel{\vec{n}}{\stackrel{\vec{Z}}{4}}$ & 它. & $\begin{array}{l}\tilde{0} \\
0 \\
0 \\
0 \\
0 \\
0\end{array}$ & $\stackrel{\mathscr{\Xi}}{\Xi}$ & 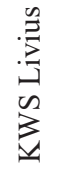 & 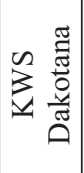 & 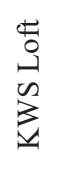 & 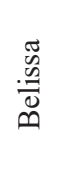 & $\begin{array}{l}\tilde{n} \\
\tilde{n} \\
0 \\
0\end{array}$ & $\begin{array}{l}\text { है } \\
\frac{0}{0} \\
\stackrel{0}{0}\end{array}$ & 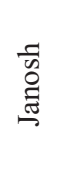 & 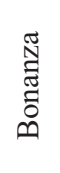 & $\begin{array}{l}\text { 昜 } \\
\text { 齐 }\end{array}$ & 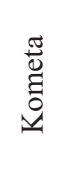 & 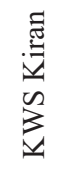 & $\stackrel{\Xi}{\Xi}$ \\
\hline \multicolumn{19}{|c|}{2016} \\
\hline $\begin{array}{l}\text { Standardowy } \\
\text { Standard } \\
\text { (A1) }\end{array}$ & 6,5 & 7 & 6,5 & 6,5 & 6,5 & 7,5 & 6,5 & 5,5 & 6 & 5 & 6 & 5,5 & 6,5 & 6 & 6 & 6 & 7 & 6 \\
\hline $\begin{array}{l}\text { Intensywny } \\
\text { Intensive } \\
\text { (A2) }\end{array}$ & 7,5 & 7,5 & 7 & 7 & 7,5 & 8 & 7,5 & 7,5 & 7 & 7,5 & 7 & 6 & 7 & 6,5 & 6,5 & 6,5 & 7,5 & 6,5 \\
\hline \multicolumn{19}{|c|}{2017} \\
\hline $\begin{array}{l}\text { Standardowy } \\
\text { Standard } \\
\text { (A1) }\end{array}$ & 8 & 8 & 8 & 8 & 8 & 7 & 8 & 6,5 & 6 & 6 & 7,5 & 6,5 & 6,5 & 6,5 & 6,5 & 7 & 6,5 & 6,5 \\
\hline $\begin{array}{l}\text { Intensywny } \\
\text { Intensive } \\
\text { (A2) }\end{array}$ & 9 & 9 & 9 & 9 & 8,5 & 8 & 8,5 & 9 & 7,5 & 8,5 & 8 & 7,5 & 7,5 & 8 & 8 & 7,5 & 8 & 8 \\
\hline \multicolumn{19}{|c|}{2018} \\
\hline $\begin{array}{l}\text { Standardowy } \\
\text { Standard } \\
\text { (A1) }\end{array}$ & 9 & 9 & 9 & 9 & 9 & 9 & 9 & 9 & 9 & 9 & 9 & 9 & 9 & 9 & 9 & 9 & 9 & 9 \\
\hline $\begin{array}{l}\text { Intensywny } \\
\text { Intensive } \\
\text { (A2) }\end{array}$ & 9 & 9 & 9 & 9 & 9 & 9 & 9 & 9 & 9 & 9 & 9 & 9 & 9 & 9 & 9 & 9 & 9 & 9 \\
\hline
\end{tabular}

Tabela 3. Średnie kwadraty zmienności w ogólnej analizie wariancji

Table 3. Mean squares of variation in overall analysis of variance

\begin{tabular}{l|c|c|c}
\hline \multicolumn{1}{c|}{$\begin{array}{c}\text { Źródło zmienności } \\
\text { Source of variation }\end{array}$} & Liczba stopni swobody & \multicolumn{2}{c}{ Średnie kwadraty - Mean squares } \\
\cline { 3 - 4 } & Degree of freedom & $\begin{array}{c}\text { wariant standardowy } \\
\text { standard variant }\end{array}$ & $\begin{array}{c}\text { wariant intensywny } \\
\text { intensive variant }\end{array}$ \\
\hline Lata - Years & 2 & $20,88^{* *}$ & $25,89^{* *}$ \\
\hline Odmiany - Cultivars & 17 & $1,26^{*}$ & $1,29^{*}$ \\
\hline Odmiany $\times$ lata - Cultivars $\times$ years & 34 & 0,18 & $2,25^{*}$ \\
\hline $\begin{array}{l}\text { Regresja względem lat } \\
\text { Regression of explanatory variability }\end{array}$ & 17 & 0,15 & 0,23 \\
\hline Odchylenie od regresji - Deviation from the regression & 17 & 0,21 & 0,28 \\
\hline Błąd doświadczeń - Experimental error & 51 & 0,27 & 0,24 \\
\hline
\end{tabular}

*istotne dla $\mathrm{p}=0,05-$ significant at $\mathrm{p}=0.05, * *$ istotne dla $\mathrm{p}=0,01-$ significant at $\mathrm{p}=0.01$

siedliskowe oraz stosowaną agrotechnikę (Mirzwa-Mróz i Zamorski 2002; Weber i wsp. 2016; Kutcher i wsp. 2018). W prezentowanych badaniach zaobserwowano zróżnicowany dla odmian pszenicy ozimej stopień porażenia przez septoriozę paskowaną liści w latach występowania choroby, tj. 2016 i 2017. Najsilniej porażone były odmiany Belissa, KWS Dakotana, Delawar, przy czym dwie pierwsze z wymienionych wyraźnie reagowały na intensyfikację technologii uprawy. Przejawiało się to poprawą ich zdrowotności w warunkach intensywnej technologii uprawy. Podwyższonemu poziomowi agrotechniki przypisuje się istotną rolę w ograniczaniu występowania chorób w roślinach uprawnych. Odbywa się to głównie za sprawą poprawy kondycji roślin, a tym samym ich zdolności do obrony przed patogenami (Rachoń i wsp. 2018). Wiodącą rolę w tym względzie odgrywa jednak racjonalnie prowadzona ochrona fungicydowa (Wyczling i wsp. 2005; Piekarczyk 
Tabela 4. Zmienność plonowania odmian pszenicy ozimej w wariancie standardowym i intensywnym technologii uprawy Table 4. Yield variability of winter wheat cultivars under standard and intensive variant of cultivation

\begin{tabular}{|c|c|c|c|c|c|c|c|c|}
\hline \multirow[b]{2}{*}{$\begin{array}{l}\text { Odmiany } \\
\text { Cultivars }\end{array}$} & \multicolumn{4}{|c|}{$\begin{array}{l}\text { Wariant standardowy }- \text { Standard variant } \\
\text { (A1) }\end{array}$} & \multicolumn{4}{|c|}{$\begin{array}{l}\text { Wariant intensywny - Intensive variant } \\
\qquad(\mathrm{A} 2)\end{array}$} \\
\hline & $\begin{array}{c}\text { średni plon } \\
\text { mean yield } \\
{[\mathrm{t} / \mathrm{ha}]}\end{array}$ & $\begin{array}{l}\text { ocena efektu } \\
\text { głównego } \\
\text { estimation } \\
\text { of main } \\
\text { effect }\end{array}$ & $\begin{array}{l}\text { stat. F dla } \\
\text { efektu } \\
\text { głównego } \\
\text { F-stat. for } \\
\text { main effect }\end{array}$ & $\begin{array}{l}\text { stat. F dla } \\
\text { interakcji } \\
\text { F-stat. for } \\
\text { interaction }\end{array}$ & $\begin{array}{c}\text { średni plon } \\
\text { mean yield } \\
{[\mathrm{t} / \mathrm{ha}]}\end{array}$ & $\begin{array}{l}\text { ocena efektu } \\
\text { głównego } \\
\text { estimation } \\
\text { of main } \\
\text { effect }\end{array}$ & $\begin{array}{l}\text { stat. F dla } \\
\text { efektu } \\
\text { głównego } \\
\text { F-stat. for } \\
\text { main effect }\end{array}$ & $\begin{array}{l}\text { stat. F dla } \\
\text { interakcji } \\
\text { F-stat. for } \\
\text { interaction }\end{array}$ \\
\hline KWS Ozon & 7,77 & 0,122 & 0,12 & 1,50 & 8,87 & 0,481 & $2,66^{*}$ & $4,68^{*}$ \\
\hline Patrias & 7,34 & $-0,311$ & $12,54^{*}$ & 2,10 & 8,42 & 0,025 & 0,00 & $2,61 *$ \\
\hline Artist & 8,11 & 0,460 & $36,01^{*}$ & 0,07 & 8,71 & 0,315 & 1,24 & 1,06 \\
\hline RGT Kilimanjaro & 7,39 & $-0,258$ & 1,02 & 0,76 & 8,17 & $-0,217$ & 1,88 & 0,33 \\
\hline Ostroga & 7,74 & 0,087 & 0,09 & 0,98 & 8,80 & 0,413 & $2,55^{*}$ & 1,46 \\
\hline Linus & 8,01 & 0,360 & $12,75^{*}$ & 0,12 & 8,58 & 0,185 & 1,48 & 0,31 \\
\hline KWS Livius & 7,74 & 0,090 & 0,29 & 0,32 & 8,49 & 0,100 & 0,81 & 0,16 \\
\hline KWS Dakotana & 7,54 & $-0,115$ & 0,68 & 0,22 & 8,26 & $-0,135$ & 0,80 & 0,30 \\
\hline KWS Loft & 7,87 & 0,217 & 0,70 & 0,78 & 8,67 & 0,280 & 2,56 & 0,41 \\
\hline Belissa & 6,85 & $-0,803$ & $57,83^{*}$ & 0,13 & 7,64 & $-0,754$ & $15,02 *$ & 0,50 \\
\hline Consus & 7,46 & $-0,195$ & 1,43 & 0,31 & 8,33 & $-0,057$ & 0,04 & 1,14 \\
\hline Delawar & 7,70 & 0,054 & 0,02 & 1,85 & 8,42 & 0,028 & 0,00 & $2,99 *$ \\
\hline Janosch & 7,47 & $-0,178$ & 3,97 & 0,09 & 7,98 & $-0,312$ & 5,26 & 0,43 \\
\hline Bonanza & 7,64 & $-0,011$ & 0,00 & 0,75 & 8,18 & $-0,207$ & 0,70 & 0,81 \\
\hline Hybery & 7,86 & 0,207 & 1,32 & 0,38 & 8,56 & 0,173 & 1,91 & 0,21 \\
\hline Kometa & 7,60 & $-0,046$ & 0,21 & 0,12 & 8,32 & $-0,067$ & 0,45 & 0,13 \\
\hline KWS Kiran & 7,98 & 0,327 & $34,66^{*}$ & 0,04 & 8,56 & 0,171 & 1,25 & 0,31 \\
\hline LG Jutta & 7,64 & $-0,008$ & 0,00 & 1,20 & 8,07 & $-0,320$ & 1,25 & 0,09 \\
\hline
\end{tabular}

*istotne dla $\mathrm{p}=0,05$ - significant at $\mathrm{p}=0.05$

A1. wariant standardowy - standard variant

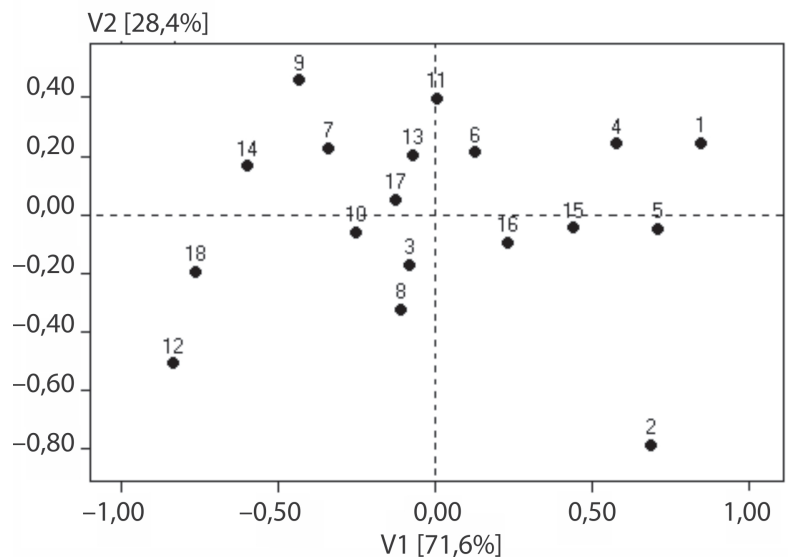

A2. wariant intensywny - intensive variant

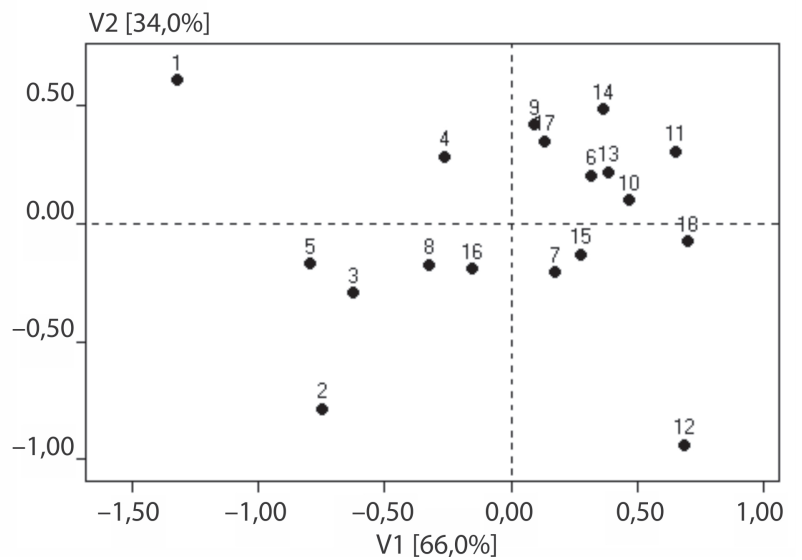

Rys. 1. Zmienność plonowania odmian pszenicy ozimej w układzie składowych głównych

Fig. 1. Yield variability of winter wheat cultivars in the system of principal components

Objaśnienia - Explanation: 1 - KWS Ozon, 2 - Patrias, 3 - Artist, 4 - RGT Kilimanjaro, 5 - Ostroga, 6 - Linus, 7 - KWS Livius, 8 - KWS Dakotana, 9 - KWS Loft, 10 - Belissa, 11 - Consus, 12 - Delawar, 13 - Janosch, 14 - Bonanza, 15 - Hybery, 16 - Kometa, 17 - KWS Kiran, 18 - LG Jutta 
i Lemańczyk 2013). Duże znaczenie ma również poziom nawożenia azotowego, a jego wpływ jest zróżnicowany w zależności od warunków meteorologicznych oraz gatunku grzyba powodującego chorobę (Gala-Czekaj i wsp. 2013). Istnieje również ścisła zależność pomiędzy współdziałaniem nawożenia azotowego i stosowaniem fungicydów w kształtowaniu stopnia porażenia roślin. Autorzy uważają również, że trudno jednoznacznie stwierdzić czy zwiększone, bądź też standardowe nawożenie azotowe przyczynia się do wzrostu porażenia roślin, ponieważ istnieje optymalne dla rozwoju $S$. tritici stężenie azotu w liściach pszenicy ozimej (Ishikawa i wsp. 2012).

O przydatności do uprawy $w$ danym regionie $i$ na określonym poziomie agrotechniki decyduje nie tylko wysokość plonowania, lecz również stabilność uzyskiwanych plonów. Określa się, że odmiana plonująca stabilnie to taka, której średnie plony nie ulegają większym wahaniom w różnych środowiskach (Oleksiak i Mańkowski 2005). Przeprowadzone doświadczenia wykazały, że potencjał plonowania badanych odmian pszenicy ozimej był zróżnicowany dla obu poziomów agrotechniki. Odmiany Artist, KWS Kiran i Linus dawały istotnie wyższe w porównaniu ze średnią ogólną plony ziarna, gdy były uprawiane w wariancie standardowym. Można je więc zalecać do uprawy w ocenianych warunkach klimatyczno-glebowych, nawet stosując bardziej oszczędną agrotechnikę. W wariancie intensywnym istotnie wyższym plonowaniem wyróżniały się odmiany KWS Ozon i Ostroga, jednak pierwsza $\mathrm{z}$ nich dawała zmienne plony w okresie doświadczenia. $Z$ tego powodu nie zaleca się jej uprawiać w ocenianych warunkach klimatyczno-glebowych oraz przy stosowaniu intensywnej agrotechniki.

W prezentowanych badaniach, w warunkach standardowego poziomu agrotechniki wszystkie oceniane odmiany pszenicy ozimej dawały zbliżone plony ziarna. Istotnie zmienne plony osiągnięto natomiast dla kilku odmian uprawianych w wariancie intensywnym, co sugeruje że intensyfikacja produkcji pszenicy ozimej odgrywa znaczną rolę w kształtowaniu tej cechy. Wiąże się to ze zróżnicowaną reakcją odmian na wyższe dawki nawożenia, bądź też stosowaniem fungicydów lub retardantów. Szczególnie duże znaczenie w omawianej kwestii przypisuje się poziomowi nawożenia azotowego, które jest najsilniejszym czynnikiem plonotwórczym.

\section{Wnioski / Conclusions}

1. Zdrowotność pszenicy ozimej była zróżnicowana w zależności od odmiany oraz warunków meteorologicznych. W sezonie z deficytem opadów (rok 2018) nie zaobserwowano porażenia roślin, natomiast w latach z optymalną ilością opadów (lata 2016-2017) wystąpiły objawy septoriozy paskowanej liści pszenicy.

2. W największym stopniu porażone były odmiany pszenicy ozimej Belissa, Delawar, KWS Dakotana uprawiane w wariancie standardowym.

3. Odmiana Belissa odznaczała się najniższym poziomem plonowania w obu wariantach uprawy. Najlepiej plonującymi odmianami pszenicy ozimej w wariancie standardowym były: Artist, Linus i KWS Kiran, a w wariancie intensywnym: KWS Ozon i Ostroga.

4. Każda z ocenianych odmian pszenicy ozimej uprawiana w wariancie standardowym plonowała na zbliżonym poziomie w okresie doświadczenia, natomiast w wariancie intensywnym zmienne plony dawały odmiany KWS Ozon, Patrias i Delawar.

Opracowanie wykonano w ramach zadania $2.3 \mathrm{w}$ Programie Wieloletnim 2016-2020 Instytutu Uprawy Nawożenia i Gleboznawstwa - Państwowego Instytutu Badawczego.

\section{Literatura / References}

Caliński T., Czajka S., Kaczmarek Z. 1987a. A model for the analysis of series of experiments repeated at several places over a period of years. I. Theory. Biuletyn Oceny Odmian 10: 7-33.

Caliński T., Czajka S., Kaczmarek Z. 1987b. A model for the analysis of series of experiments repeated at several places over a period of years. I. Example. Biuletyn Oceny Odmian 10: 35-71.

Gala-Czekaj D., Gorczyca A., Oleksy A. 2013. Zdrowotność pszenicy twardej odmiany Komnata w zależności od dawki nawożenia azotowego. [The health status of durum wheat of cultivar Komnata depending on dose of nitrogen fertilization]. Episteme 21 (2): 393-403.

Ishikawa S., Hare M.C., Kettlewell P.S. 2012. Effects of strobilurin fungicide programmes and fertilizer nitrogen rates on winter wheat: severity of Septoria tritici, leaf senescence and yield. The Journal of Agricultural Science 150 (4): 411-426. DOI: 10.1017/ S0021859611000670.

Jarecki W., Buczek J., Bobrecka-Jamro D. 2014. Reakcja pszenicy jarej odmiany Kandela na zróżnicowaną intensywność uprawy. [Reaction of spring wheat cultivar Kandela to diversified intensity of cultivation]. Fragmenta Agronomica 31 (3): 58-65.

Kołodziejczyk M., Szmigiel A. 2014. Wpływ intensywności technologii uprawy na plonowanie wybranych odmian pszenicy jarej. [Influence of intensity cultivation technology on yielding of some spring wheat cultivars]. Fragmenta Agronomica 31 (3): 75-84.

Kutcher H.R., Turkington T.K., McLaren D.L., Irvine R.B., Brar G.S. 2018. Fungicide and cultivar management of leaf spot diseases of winter wheat in Western Canada. Plant Disease 102 (9): 1828-1833. DOI: 10.1094/PDIS-12-17-1920-RE.

Lista odmian roślin rolniczych wpisanych do krajowego rejestru w Polsce. 2018. COBORU, Słupia Wielka: 53-56. 
Mirzwa-Mróz E., Zamorski C. 2002. Podatność genotypów pszenicy ozimej na porażenie przez Mycosphaerella graminicola [Fuckel] Schroeter. [Reaction of winter wheat genotypes to infection by Mycosphaerella graminicola [Fuckel] Schroeter]. Acta Agrobotanica 55 (1): 233-246. DOI: 10.5586/aa.202.022.

Oleksiak T., Mańkowski D.R. 2005. Interakcja odmian pszenicy ozimej w zmiennych warunkach środowiskowych na podstawie wyników badań ankietowych. [Interaction of wheat cultivars in variable environmental conditions on the basis of survey investigation]. Biuletyn Instytutu Hodowli i Aklimatyzacji Roślin 235: 5-11.

Piekarczyk M., Lemańczyk G. 2013. Wpływ nawożenia azotem na zdrowotność wybranych odmian pszenicy ozimej uprawianych na glebie lekkiej. [Effect of nitrogen fertilization on health status of some winter wheat cultivars grown on light soil]. Progress in Plant Protection 53 (3): 494-497. DOI: 10.14199/ppp-2013-052.

Rachoń L., Szumiło G., Bobryk-Mamczarz A. 2018. Podatność na choroby grzybowe wybranych genotypów pszenicy ozimej w zależności od poziomu agrotechniki. [Susceptibility of selected winter wheat genotypes to fungal diseases in relation to the level of cultivation technology]. Agronomy Science LXXIII (1): 29-39. DOI: 10.24326/asx.2018.1.3.

Weber R., Bujak H. 2016. Zmienność plonowania wybranych odmian pszenżyta ozimego w zależności od technologii uprawy i środowiska. [Variability yielding of winter triticale varieties according to cultivation technology and environment]. Fragmenta Agronomica 33 (1): $87-95$.

Weber R., Bujak H., Nowosad K. 2016. Analiza zmienności porażenia odmian pszenicy ozimej na Dolnym Śląsku przez grzyb Puccinia recondita f. sp. tritici. [Variability analysis of infection winter wheat cultivars in Lower Silesia by fungus Puccinia recondita f. sp. tritici]. Progress in Plant Protection 56 (1): 89-95. DOI: 10.14199/ppp-2016-016.

Wyczling D., Pańka D., Lenc L., Sadowski C. 2005. Wpływ ochrony fungicydami na zdrowotność i plon pszenicy ozimej. [Influence of herbicide protection on health status and yielding of winter wheat]. Acta Agrobotanica 58 (2): 287-306. 